\begin{tabular}{|l|l|l|}
\hline \multicolumn{2}{|c|}{ PublisherInfo } \\
\hline \hline PublisherName & $:$ & BioMed Central \\
\hline \hline PublisherLocation & $:$ & London \\
\hline \hline PublisherImprintName & $:$ & BioMed Central \\
\hline \hline
\end{tabular}

\title{
Olfactory research wins Nobel
}

\begin{tabular}{|l|l|l||}
\hline \multicolumn{2}{|c|}{ ArticleInfo } \\
\hline \hline ArticleID & $:$ & 5004 \\
\hline \hline ArticleDOI & $:$ & $10.1186 /$ gb-spotlight-20041004-01 \\
\hline \hline ArticleCitationID & $:$ & spotlight-20041004-01 \\
\hline \hline ArticleSequenceNumber & $:$ & 67 \\
\hline \hline ArticleCategory & $:$ & Research news \\
\hline ArticleFirstPage & $:$ & 1 \\
\hline \hline ArticleLastPage & $:$ & 3 \\
\hline \hline & & RegistrationDate : 2004-10-4 \\
\hline ArticleHistory & $:$ & OnlineDate \\
\hline \hline ArticleCopyright & $:$ & BioMed Central Ltd2004-10-4 \\
\hline \hline ArticleGrants & $:$ & \\
\hline \hline ArticleContext & $:$ & 130595511 \\
\hline \hline
\end{tabular}




\section{Stephen Pincock}

Email: stephen@thescientisteurope.com

Richard Axel, of the Howard Hughes Medical Institute at Columbia University, NY, and Linda B. Buckfrom Fred Hutchinson Cancer Research Center in Seattle, Wash., have been awarded the 2004 Nobel Prize in Physiology or Medicine.

The Nobel Assembly at Karolinska Institutet said the two researchers were being recognized for their discovery of odorant receptors and the organization of the olfactory system. Their seminal paper, in which they described the large family of roughly 1000 genes for odorant receptors, was a watershed in the field.

"This has been of pretty immense significance," said Tim Jacob, professor of physiology at the School of Biosciences at Cardiff University, UK. "Their work has opened the door to all the current investigations trying to crack the molecular code of smells or tastes."

"Until their discovery, drawings of how olfaction takes place had a black box for reception," Matthew Cobb, from the faculty of life sciences at Manchester University, told us.

The two researchers showed that about 1000 genes - or roughly $3 \%$ of our genes - are used to code for the different odorant receptors on the membrane of olfactory receptor cells, although in humans, most are pseudogenes and only around 350 code for functional receptors. They also showed that this large family of odorant receptors are $\mathrm{G}$ protein - coupled receptors.

The two researchers were among many who were trying to understand the olfactory system. According to Axel, the breakthrough discovery came when Buck - a graduate student in his lab at the time - came up with "an extremely clever twist."

In a statement from Howard Hughes Medical Institute, Axel said Buck made three assumptions that drastically narrowed the field. First was that the receptors would be G protein-coupled receptors. Next, she assumed that the odorant receptors were members of a large family of related proteins. Third, the genes had to be expressed only in a rat's olfactory epithelium.

"Had we employed only one of these criteria, we would have had to sort through thousands more genes," said Axel. "This saved several years of drudgery."

"I had tried so many things and had been working so hard for years, with nothing to show for it," Buck said in the statement. "So when I finally found the genes in 1991, I couldn't believe it! None of them had ever been seen before. They were all different, but all related to each other. That was very satisfying."

Independently, Axel and Buck showed that every olfactory receptor cell expresses only one odorant receptor gene. They also independently showed that receptor cells carrying the same type of receptor converge into the same glomerulus, the Nobel Assembly said.

The research has been influential in fields beyond sensory reception, noted Barry Keverne, professor of behavioral neuroscience at the University of Cambridge. "It's not only olfaction," he told us. "It's 
helping us now to understand the evolution of the genome." In the wake of Buck and Axel's work, there has been an explosion of research into the phylogeny of olfactory receptors.

\section{References}

1. Richard Axel, [http://www.hhmi.org/research/investigators/axel.html]

2. Linda B. Buck, [http://www4.nationalacademies.org/nas/

naspub.nsf/(urllinks)/NAS-5MLFAP?opendocument\&Start=1\&Count=1000\&ExpandView]

3. The 2004 Nobel Prize in Physiology or Medicine, Nobel Prize press release, October 4, 2004., [http://nobelprize.org/medicine/laureates/2004/press.html]

4. A novel multigene family may encode odorant receptors: a molecular basis for odor recognition

5. Tim Jacob, [http://www.cf.ac.uk/biosi/staff/jacob/index.html]

6. Matthew Cobb, [http://www.biomed.man.ac.uk/staff/user.asp?id=1675\&item=Contact + Details $]$

7. Richard Axel and Linda Buck Awarded 2004 Nobel Prize in Physiology or Medicine, Howard

Hughes Medical Institute press release, October 4, 2004., [http://www.hhmi.org/news/2004nobel.html]

8. Barry Keverne, [http://www.zoo.cam.ac.uk/zoostaff/keverne.htm]

This PDF file was created after publication. 